\title{
2
}

\section{Shifting cultural affinities in Molloy: A genetic bilingual approach}

\section{Dirk Van Hulle and Pim Verhulst}

\section{Introduction}

For a work of fiction to have 'an effective life as world literature', according to David Damrosch, it needs to be 'actively present within a literary system beyond that of its original culture' (2003: 4). At first glance, Beckett's work seems to amply meet that requirement, having reached a wide readership and elicited a critical response beyond English, French and German - i.e. the three main languages in which he regularly wrote or translated his work, sometimes with the help of third parties. But what exactly is its 'culture of origin'? In the beginning of Beckett's career, one might argue it was Ireland, even though he turned his back on its literary and cultural life in the late 1930s, after travelling to Italy, France, England and Germany. However, was Irish still the 'culture of origin' for Beckett's work by the end of his life in 1989, when he had actually spent more years living in the city of Paris and his country house in Ussy-sur-Marne than in his native Dublin suburb of Foxrock? Did the one supplant the other, or had they established a form of coexistence over the intervening decades? These questions are especially pertinent with regard to Beckett's so-called 'trilogy' of novels. 
Molloy, Malone meurt/Malone Dies and L'Innommable/The Unnamable were written in French between 1947 and 1950, just after the Second World War and Beckett's return to Paris from Rousillon by way of Saint-Lô, in what he described to his biographer, James Knowlson, as the 'siege in the room' or the 'frenzy of writing'. He then translated the novels into English Molloy with the help of Patrick Bowles, on and off between 1950 and 1958. ${ }^{1}$ This decade marked a transitional period in Beckett's literary career, during which he first switched to an adopted language, only to reconnect with his mother tongue later on by way of self-translation as well as original composition. That Beckett himself was unsure as to how long his linguistic exile would last is clear from a bio that he drafted at the back of the second notebook containing the original French manuscript of Molloy. After listing some poems, a book of stories (More Pricks Than Kicks) and a novel (Murphy), he ends by saying that he has been writing in French since 1945, tellingly crossing out the word 'exclusively': 'Depuis 1945 écrit en français. exclusivement' (BDMP4: FN2, 144v). ${ }^{2}$ This same sense of indetermination also affected the prose that he was literally in the middle of writing.

For Leslie Hill, the trilogy exudes an 'unmistakable sense of unbelonging' that lends it a 'hybrid status': 'Though composed in one language, French, the novels gesture towards another, Anglo-Irish' (1990: 40). As Emilie Morin points out, this observation is not limited to the original text but also pertains to the translation, since 'comparing English and French versions forbids a straightforward alignment with an Irish setting and Irish origins' (2009: 61). Sinéad Mooney describes the cross-cultural identity of the trilogy as a 'Babel-like in-betweenness': 'It is caught [...] between France and Ireland, and the demands of "source" and "target" languages and cultures, although it is never plain which role of the two French and English play' (2011: 123). Because Beckett first wrote the novels in the language of Molière, they 'present a savagely reduced world that always already feels like an eccentric translation into French from some non-existent HibernoEnglish original' (134), which only came into being post factum. For the purpose of this chapter, we wish to limit our focus to Molloy, in both French and English. In addition to being more grounded in external reality than Malone meurt/Malone Dies, L'Innommable/The Unnamable, it was the first instalment of a larger-scale project that forced Beckett to examine his position as an Irish author in a French literary field, while at the same time it exposed him to an international market via translation.

Whereas the culturally divided status of Molloy has already been acknowledged, our purpose is to explore what genetic criticism can add to its understanding and to the study of world literature in general. ${ }^{3}$ According to Pierre-Marc de Biasi, the task of critique génétique is twofold: (1) to classify, transcribing and making public all the available pre-publication material of a literary work (notes, manuscripts, typescripts, proofs, etc.); (2) to reconstruct the creative dynamics of the writing process from a particular 
critical vantage point (2004: 42). By analysing the extant manuscripts of Molloy from the perspective of world literature, 'in the making' so to speak, it becomes possible to understand how Beckett crafted this famous effect of cultural displacement, in French and in English, after careful revision and shifting cultural affinities. Additionally, our genetic bilingual analysis of Molloy will reveal that the referential framework of the novel extends well beyond the Irish-French dichotomy to which it is often confined and that it also includes British, German and American culture, especially in translation, but already in the original.

\section{The French Molloy}

While the setting of the French Molloy has widely been recognized as vaguely Anglo-Irish, the published text never identifies it as such in explicit geographical terms. The manuscript was quite different in this respect. For example, Molloy cannot remember the name of his town, thinking it starts with 'un D', as in Dublin (BDMP4: FN2, 07r), whereas the published version replaces the letter 'D' with 'un B' or 'un P' (1951: 45), which undoes the reference. Something similar happens when Moran dispatches his son, Jacques, to get a bicycle in the nearest village. In the manuscript, it is not called 'Hole' but 'Carrick' or 'Carrig' (BDMP4: FN3, 90r, 94r), a common place name resembling Carrickmines, the suburb south of Dublin between Dalkey and Bray where Beckett used to play golf. However, another revision to the text invokes Dublin again, albeit in a more opaque fashion. In the manuscript, Molloy finds himself near a canal - 'me voilà [...] aux bords du canal' (BDMP4: FN1, 69r) - but Beckett adds on a second one for the published text: 'il y en a même deux' (1951: 38). This revision strengthens the suggestion that the setting might be Dublin after all, with its Royal and Grand Canals, but many other cities share this characteristic so that it becomes a playful allusion opening up the text to multiple possibilities rather than pinpointing it to one exact location.

It is not just references to Ireland that undergo this treatment in the writing process. When Moran is attempting to describe the size of his region and explains that 'in modern countries this is what I think is called a commune, or a canton' (2009a: 139), Beckett used France as a point of comparison in the manuscript, be it after a few false starts: 'C'était ee qu'on appelle en Fra ee que les Français appellent une eommune on appelle en tune eom En France on appelle ça une commune' (BDMP4: FN3, 63r). In the published version of Molloy, this explicit invocation was generalized to 'les pays évolués' (1951: 207), thus contrasting a by now vaguely hinted Ireland with any foreign country more advanced. The phrase differs conspicuously from the one printed on Professor Suk's sheet in Murphy: 'Famous throughout 
Civilised World and Irish Free State' (2009b: 22). For an English-language novel about the marginalized position of Irishmen in London (see Bixby 2010; Davies 2017) such frankness makes sense, but for his Anglo-Irish novel in French Beckett adopted a different approach. In the revised version of the sentence, Moran aligns himself neither against the Irish Free State - as in Murphy - nor with the French Republic - as in the drafts of Molloy settling instead for the middle ground of a cultural no man's land.

The passage discussed above is one of the rare instances where Beckett uses the word 'pays' or 'country' to denote a nation or state. Another example is when Lousse tells Molloy she has no other means of support than the pension of her departed husband, who has 'fallen in defence of a country that called itself his and from which in his lifetime he never derived the smallest benefit, but only insults and vexations' (2009a: 30-1). While this comment may be construed as 'an allusion to Irish involvement in the Great War under the British flag' (Morin 2009: 91-2), it is nondescript enough to represent a general 'alienation of citizens from states' (Harrington 1991: 164). Still, the word 'patrie' in the original French - 'une patrie qui se disait la sienne et dont de son vivant il ne retira jamais le moindre avantage, mais seulement des affronts et des bâtons dans les roues' (1951: 48) - underlines the patriotic or nationalist connotations of the remark, which Beckett is careful not to overuse in other sections of the novel. When Molloy explains that where he comes from, the word ' $\mathrm{da}$ ' is used to mean 'father', as in Ireland, he originally refers to the place as 'ma putain de patrie' (BDMP4: FN1, 36r) - 'my fucking country' - before rephrasing it as 'ma région' (1951: 23) - 'my region' - in the published text. In translation, this even becomes 'my part of the world' (2009a: 50), situating it on the global map rather than enclosing it within national or regional borders.

Roughly the same phrase is used when Molloy describes the weather 'in that part of the world' (2009a: 28) - 'dans cette région' (1951: 44), 'ce pays' in the manuscript (BDMP4: FN2, 05r) - as sunny till noon, rainy the whole day, followed by a brief glimpse of sunlight before darkness descends, which is again characteristic of Ireland. A crucial difference is that Molloy has now put a distance between himself and his place of origin, by means of the determiner 'that' in English and 'cette' in French. This becomes a pattern in the later stages of the genesis, when Beckett adds various phrases to hint that Molloy is now in a different, undisclosed location. About the blandness of the weather, he now remarks, 'Ça a peut-être changé depuis' (1951: 76) - 'Perhaps things have changed since then' (2009a: 50). Apart from obscuring the name of Molloy's home country and further removing him from it physically, Beckett also subdues a potential disclosure of the character's ethnicity. Confessing that he fears the 'far whisper' in his head, Molloy goes on in the manuscript: 'à l'égal [...] des anglo-saxons' (BDMP4: FN2, 25r). This is another remark that might have identified him as IrishCeltic, which would have given him good reason, historically speaking, to 
be wary of Anglo-Saxons, not long after the Easter Rising of 1916, with its violent build-up and bloody aftermath.

Up to a certain point in the novel's genesis, it seems that Beckett considered mixing elements of Anglo-Irish with French culture to destabilize the frame of reference. A case in point is a longer episode omitted from the published text but still present in the manuscript and typescript of Molloy. It occurred when Moran states, 'What then was the source of Ballyba's prosperity? I'll tell you', at which point a lengthy but amusing digression on the subject followed, which Beckett simply cut and replaced with 'No, I'll tell you nothing. Nothing' (2009a: 140). On the one hand, this passage detailing the particulars of Ballyba's agrarian economy centred on human excrement has been read by Adam Winstanley as a Swiftian critique of '[Éamon] de Valera's vision of a self-sufficient Ireland' (2014: 97), when the Irish Free State elected to pursue a policy of economic protectionism and to build an 'indigenous' industry, 'producing primarily for the home market' (Neary and Ó Gráda 1991: 250). On the other hand, references to French culture delocalize and broaden this complex satire. Moran mentions a character called Colbert, who amassed a fortune simply by eating, defecating and selling his excess faeces to the needy. Given the commercial context of the episode, a name like 'Colbert' could easily refer to Jean-Baptiste Colbert, the Minister of Finances under Louis XIV, who reformed the domestic economy, introduced a fairer tax system and improved the mode of collection in France. An interesting detail is that he suffered frequent stomach aches, which limited his meals to bread soaked in broth. The fictional Colbert is so revered by the poor that he deserves a statue, Moran feels, who believes the sitting posture would be most fitting: 'Assis j'espère' (BDMP4: FT, 222r). Not coincidentally, perhaps, the historical figure of Jean-Baptiste Colbert is honoured with a statue in front of the Assemblée nationale in Paris, depicting him seated with left hand raised.

Another curious example of cultural intermingling is the way Beckett uses distances in the drafts of the novel. When Molloy explains that he has never put more than ' 10 ou 15 kilomètres'_-'10 or 15 kilometres' - between himself and the town where he was born, this later becomes 'quinze ou vingt milles' (1951: 44) - 'ten or fifteen miles' (2009a: 28). What appears to be a simple conversion from the Franco-European metric system to AngloIrish imperial measurements in the first part of Molloy is complicated by the use of distances in the second part. Moran, expressing the size of the area he inhabits, already does so in square miles in the manuscript, not in kilometres: '5 ou 6 milles carrés' (BDMP4: FN3, 63r). However, they still occur every now and then, when he estimates the distance to the nearest town at '15 kilomètres' (BDMP4: FN3, 91r), not changed until the published text to 'quinze milles' (1951: 218) - 'fifteen miles' (2009a: 147). This suggests that Beckett had decided on switching to the imperial system by the time he reached Part II in the manuscript, occasionally relapsing 
into his old habits from the Molloy part and normalizing everything later. However, if we look at the way currencies occur in the drafts, it is possible that Beckett at least considered using different cultural frames of reference for Molloy and Moran, with the miles in the second part suggesting not an Anglo-Irish but an American setting.

Molloy never mentions money except in the vaguest of terms, contrary to Moran's part. The value of young Jacques's Timor stamp is given at ' 40 cents' (BDMP4: FN3, 15r) in the manuscripts, later revised to 'un florin' (1951: 246) - 'a florin' (2009a: 113). It is not an American stamp, as his pocket money - 'chaque cent qu'il recevait' (BDMP4: FN3, 57r) - is also expressed in that monetary unit, later becoming 'chaque penny' (1951: 202) - 'every penny he received' (2009a: 136). As with distances, Beckett eventually transposes everything to the currencies of Ireland and England. Yet one major difference is that the original values in the manuscript are not French, which uses 'centime' as the decimal unit, not 'cent'. So much is borne out by the larger amounts that occur in the drafts. The weekly wages of Gaber and Moran amount to '40 dollars' and '32' dollars (BDMP4: FN3, 11r), which, after exchange, become 'huit livres' and 'six et demie' (1951: 165) - 'eight pounds' and 'six pounds ten' (2009a: 111). They are not getting their money from abroad, because Moran also sets the maximum price of the bicycle that his son is to buy at ' 40 dollars' in the manuscript (BDMP4: FN3, 90r), later revised to 'cinq livres' (1951: 218) - 'five pounds' (2009a: 147). So, rather than inscribing Molloy as a novel within a unified cultural context from the outset, simply swapping the Franco-European setting with an Anglo-Irish one further in the writing process, Beckett sought to destabilize straightforward identifications between the two parts, even using a currency as foreign as American dollars to maximize that effect. While the published French version, after revision, eventually shows 'an adherence to anglophone norms of measurement' (Morin 2009: 60), this was certainly not yet the case in the manuscripts.

The overall adjustment of the measurements and currencies to AngloIrish norms was a late change, as the partially surviving typescript of Molloy reveals. References to American money had been removed by this stage, as the value of shit per weight in the aforementioned 'Ballyba' episode was still given as 'douze à quinze cents le kilog brut' in the manuscript but changed to 'onze cinq à sept pence le kilog brut' (BDMP4: FT, 215r) - 'five to seven pence per gross kilogramme'- in the typescript. While the passage was eventually removed in its entirety, the fact that metric units had not yet been changed to imperial pounds confirms that Beckett continued revising them over a longer period of time, here allowing the Anglo-Irish currency - still American in the drafts - to coexist with a Franco-European unit of mass in the selfsame sentence. As we will see in the following section, this process of cultural destabilization continued in the English translation. 


\section{The English Molloy}

The eventual adoption of Anglo-Irish measurements and currencies in French seems to have briefly inspired its expansion into other areas of the novel in English, for example beverages. Molloy's 'cinq ou six pots de bière' (1951: 81) at first became 'five or six Imperial pints of porter' (BDMP4: ET1, 63r), a measurement equal to $1 / 8$ th of an imperial gallon that is only used in the UK and Ireland. Beckett downplays the Anglo-Irish reference again to 'mugs of beer' (BDMP4: ET2, 63r) on the second typescript, yet in other cases he replaces general French terms with English equivalents that emphasize the Anglo-Saxon setting of the novel, slightly heightening its Britishness in Moran's part. His 'pommier', for example, becomes an 'apple tree Beauty of Bath, (BDMP4: ET2, 02r), a popular dessert apple no longer commercially grown because it bruises easily, but which is still a common garden variety. Another instance occurs when Moran refers to his 'carpette' (BDMP4: FN3, 15v) in French, later changed to his 'moquette' (1951: 168) for the published text, possibly to pun on the expression 'fumer la moquette' ('to talk nonsense'). The English translation hesitates between the brand names 'Axminster Wilton' (BDMP4: ET2, 22r), types of carpet manufactured in Devon and Wiltshire, eventually settling for the latter.

The reverse also occurs, when a specific brand name in the French version is replaced with a more neutral term in the translation. One interesting example is 'baume Bengué' (1951: 87), an ointment to soothe muscle pains that Molloy administers to Edith's rump. In English, Beckett doubted between 'wintergreen ${ }^{\text {cream' }}$ (BDMP4: ET2, 67r), the first being a blanket term for oil extracted from the Gaultheria plant, which is used as a folk remedy for arthritis, poor blood circulation, rheumatism, inflammation or tendinitis, and the latter a general term for ointments with a similar function. The term 'baume Bengué' stands out in the original Molloy because the story is vaguely set in an AngloIrish context, where a French brand name would seem exotic. Beckett also used the term in Part II, when Moran feels a sharp pain in his knee and asks his son Jacques to bring him 'du Baume Bengué de l'iodex' (BDMP4: FN3, 86r), an English brand unknown to a French readership. So what originally established symmetry between the novel's two parts was subsequently used to disrupt the cultural unity of Molloy, similar to what the different currencies effectuated in the manuscript, one character using a French brand, the other an English one to remedy ailments. By opting for 'wintercream' and 'iodex' in the English version, Beckett smooths over the dissimilarity, but he destabilizes the cultural context elsewhere in the translation.

When Moran's sore knee plays up again in the story, he shrugs it off as a touch of neuralgia and reminds himself to procure 'une boîte de thermogène, avec le joli démon dessus' (1951: 215). The phrase refers to a brand of thermogenic cotton, produced in France, which became very 
popular after 1909 thanks to a successful marketing campaign using artwork by French-Italian designer Leonetto Cappiello. As William H. Helfand explains, the colourful image of a 'fire-eating circus performer holding the product close to his chest [...] has become an icon of creative advertising imagery' (1991: 34). Though common in France, the product was little used in Ireland, the UK or the United States, so Moran's reference to 'a packet of thermogenic ${ }^{\mathrm{e}}$ wool, with the pretty demon on the outside' (BDMP4: ET2, 57r) must have been foreign to Irish-English and American readers alike. It not only disturbs the Anglo-Saxon context of the story, strengthened by some of the brand names mentioned above, but it also harks back to the novel's French origin, which is further emphasized by Beckett's preference for the unusual Gallic spelling of 'thermogene' over 'thermogenic' in the typescript.

In this respect, it is important to keep in mind that Beckett was translating Molloy into English for an audience more diversified and global than that of the French text. He had a contract with Maurice Girodias of Olympia Press, who ran an English-language publishing house out of Paris. Although Girodias was mostly known for putting out 'dirty books' or 'DBs' (de St Jorre 2009: 96), he also had a more respectable list including the 'Collection Merlin', which consisted of translations commissioned by the editors of the eponymous literary magazine. One of those titles was Molloy, converted into English by Beckett with assistance from the South African writer-translator Patrick Bowles. When the American publisher Barney Rosset, who had already taken on Waiting for Godot by this time, caught wind of Olympia and Merlin's plans for Molloy, he also signed a contract with them for its distribution in the United States. As a result, Beckett was translating for a number of international markets, encompassing more than one variety of the English language: America, the sizeable expat community in France, the UK and its Commonwealth territories. His awareness of this peculiar situation clearly impacted the translation process, as we learn from Beckett's correspondence with Grove Press. On 4 August 1953, having read the first specimen by Beckett and Bowles, Rosset made a critical comment which he referred to as 'a mention of words':

Those such as skivvy and cutty are unknown here, and when used they give the writing a most definite British stamp. That is perfectly all right if it is the effect you desire. If you are desirous for a little more vagueness as to where the scene is set it would be better to use substitutes which are of common usage both here and in Britain.

(Rosset 2016: 72)

While he sympathized with Rosset's reservations, Beckett also noted the complexity of the matter in his reply of 1 September 1953: 
I understand your point about the Anglicisms and shall be glad to consider whatever suggestions you have to make in this connexion. But the problem involved here is a far-reaching one. Bowles's text as revised by me is bound to be quite unamerican in rhythm and atmosphere and the mere substitution here and there of the American for the English term is hardly likely to improve matters, on the contrary. We can of course avoid those words which are incomprehensible to the American reader, such as skivvy and cutty, and it will be a help to have them pointed out to us.

(2011: 397-8)

The word 'skivvy' (BDMP4: Sp1-3, 02r) - 'boniche' in French (1951: 8) was eventually replaced with the more neutral term 'chambermaid' (2009a: 3), but 'cutty' (2009a: 8) - a short tobacco pipe - was retained. A playful nudge to the American public is the expletive 'fuck the son of a bitch', which Bowles suggested adding to the repertoire of Lousse's parrot (Bowles 1994: 33), prompting Molloy to conclude that the bird 'must have belonged to an American sailor' (2009a: 35). At the same time, many more decidedly unAmerican words were added to the English version during the translation process. Molloy, who admits that he 'began at the beginning, like an old fool, can you imagine that' (BDMP4: Sp1-3, 02r) in the early drafts, refers to himself with the more Irish-British term 'ballocks' in the second typescript (BDMP4: ET2, 02r). Other later-stage revisions to the novel's opening sequence give the narrator a more distinctive Anglo-Irish tone. 'It was he who told me I'd begun all wrong' (BDMP4: Sp1-3, 02r) - referring to the man who collects Molloy's pages every Sunday - was altered to 'It was he told me I'd begun all wrong' (BDMP4: ET1 02r). This same type of revision occurs further on in the text, where Molloy speaks of Lousse's dead dog, 'her Teddy whom she had loved like her own an only child' (BDMP4: ET2, $42 \mathrm{r}$ ). In both cases the pronoun is deleted, which is a typical characteristic of Hiberno-English.

Beckett's stress on 'Bowles's text as revised by me' in his letter to Rosset suggests that they deliberately enhanced its un-American flavour, while making a few concessions. At the same time, they destandardized the language by making it sound less 'English' or, perhaps more correctly, less 'British'. This notion of substandard English relates to a comment that Beckett made in a letter to Cyril Lucas of 4 January 1956, namely that he was still able to write 'the queer kind of English' that his 'queer French' deserved (2011: 591-2). As several critics have noted (Fletcher 1967; Morin 2009; Mooney 2011), Beckett's use of French in Molloy often deviates from the norm, infused as it is with Irish inflexions. Hiberno-English traits appear to fulfil a similar destabilizing function in the English version, but this is not 
to say that Beckett naturalized Molloy into an Irish novel. Although he did introduce a few outspokenly Hiberno-English traits in the earlier drafts of the translation, he removed some of these again later. As a result, the 'queer' Anglo-Irish flavour of the novel remains as subtle as the 'queer' ambiance of his non-native French, which is just slightly off-standard and conjures up a sense of Irishness while not embracing it wholeheartedly.

One of the most interesting examples in this regard is the word 'puckaun' (BDMP4: ET1, 31r), which Beckett employed in an early version of the translation for 'le bouc' (1951: 41) but later replaced with the more neutral 'buck-goat' (BDMP4: ET2, 31r). He had also used the word in Watt (1953), in the scene where 'a goat emerged, dragging its pale and chain' and Mr Nolan complains: 'Riley's puckaun again [...], I can smell him from here' (2009c: 213). 'Puckaun' is a markedly Hiberno-English word, derived from the Irish pocán, the diminutive form of the male goat poc. This provenance may explain why the term was problematic in a deliberately bi-cultural, Anglo-French text such as Molloy, but not in a more openly Anglo-Irish novel like Watt, which was inscribing itself deliberately into the 'Big House' tradition (Harrington 1981). According to the OED, the earliest use of the word 'puckaun' is encountered in Jonathan Swift, more precisely in his 'Dialogue in Hibernian Style between A and B'. In volume VII of The Works of Jonathan Swift, edited by Walter Scott, this burlesque is introduced as a 'specimen of Irishisms, or what Swift condemned as such [...] taken from an unfinished copy in the Dean's handwriting, found among Mr Lyon's papers' - a clergyman attending to him during his last years (Swift 1824: 156). Swift packs a great many examples of Irish words, phrases and syntax into a twenty-four-line conversation between two characters Beckettianly named $\mathrm{A}$ and $\mathrm{B}$, ending with the question:

A Do you make good cheese and butter?

B Yes, when we can get milk; but our cows will never keep a drop of milk without a Puckaun. (Swift 1824: 157)

Swift uses the word differently, meaning a bull instead of a male goat, so it may not be the (only) source of Beckett's 'puckaun', but the fact that it functions there as a specimen of Hiberno-English is relevant for Molloy and may explain why it was eventually replaced - evoking an Irish context all too strongly. As Molloy himself admits, he is not an expert on the Irish language, claiming as much ignorance about this subject as about the meaning of tears and laughter: 'they are so much Gaelic to me' (2009a: 35). This was a late addition, probably on the proofs, as both surviving typescripts still read 'Hebrew' (BDMP4; ET1, ET2, 42r) for the French 'je m'y connais guère' (1951: 54). Some of its most outstanding features having been removed from the text by this stage, or mixed in with other cultural references, Molloy's disavowal of Irishness seems very appropriate indeed. 


\section{The German Molloy}

In addition to the Irish, British and American elements which have been discussed until now, German culture also features significantly in the drafts of the English Molloy. This may have been triggered by Beckett's assistance of Erich Franzen with the German Molloy in January and February of 1954, when he was yet to begin translating the second part of the novel into English with Patrick Bowles. One of the issues that Beckett and Franzen disagreed about was the word 'coenaesthesis' in Molloy's claim: 'coenaesthetically speaking of course, I felt more or less the same as usual' (2009a: 53). As Beckett told Franzen, quoting from the OED in his defence, the term denoted 'the general sense of existence arising from the sum of bodily impressions', giving Wilhelm Wundt's 'Gemeinempfindung' as a roughly equivalent German philosophical concept, together with 'Coenesthesis' and 'Gemeingefühl'. Franzen, however, did not find Beckett's suggestions acceptable, explaining that 'Hitler's propaganda monopolized the term': 'if such terms which you intend to bear a special meaning, but which to Germans indicate something general (Hitler's Gemeingefühl), are used, the blame will be on the translator' (Beckett and Franzen 1984: 29). It seems that Beckett did yield to German sensitivities, as the published translation opts for a paraphrase instead, but the incident will have reminded him of his own time in Germany from 1936 to 1937, where he witnessed first-hand the appropriation of everyday language by Nazi Socialism. One of those arrogated words was 'Eintopf'.

A German stew typically consisting of a broth with vegetables, potatoes and meat, it comes in a number of varieties and denotes the method of cooking the ingredients in one pot rather than a specific recipe. Beckett recorded the term several times in his so-called German diaries (UoR MS 2901), frequently complaining of the dish's ubiquitousness and unpalatability. He also mentions the 'Eintopf-Sonntage', a propagandist initiative by the Nazi government ordering citizens and restaurants to eat or serve only cheap stew dishes on every first Sunday of the month from October to March, to support the idea of one nation eating from one pot ('Beckett's Blick' 2005: 152). According to James McNaughton, Beckett is taking issue with this type of nationalist propaganda when he introduces the word in the typescript of Watt and describes Mr Knott's pot as 'an invariable Eintopf' (McNaughton 2018: 13). Even though Beckett removed it again later, it still resonates in the following passage: 'It resembled a pot, it was almost a pot, but it was not a pot of which one could say, Pot, pot, and be comforted' (2009c: 67). Expanding on the nominalist interpretation that is usually given to this sentence, McNaughton argues that ' $[t]$ he pot is not merely, or not only, some abstract noun, but, more compellingly, an everyday object and meal supersaturated with ideological investment: specific propaganda has made it difficult to call a pot simply a pot' (2018: 
14). In the drafts of the English Molloy, the word 'Eintopf' shared a similar function - and, eventually, fate.

In the Edith episode, Molloy states that what little he ate, he devoured voraciously: 'I flung myself at the mess, gulped down the half or the quarter of it in two mouthfuls without chewing (with what would I have chewed?), then pushed it from me with loathing' (2009a: 53). In the first English typescript, Beckett still used the word 'Eintopf' (BDMP4: ET1, 63r), which did not get replaced with the more general 'mess' until the second typescript. Being a translation of what in the French version is still called a 'plat unique' (1951: 81) or 'single-course meal', it acts as a parallel to the scene in the second part of the novel where Martha has cooked a meal for Moran, who inspects it as follows: 'I peered into the pots. Irish stew. A nourishing and economical dish, if a little indigestible. All honour to the land it has brought before the world' (2009a: 101). Moran's high-flown rhetoric is strikingly similar to the Nazi propaganda Beckett mocked when defining 'Eintopf' in his German vocabulary notebook as 'arish stew = neues nationalgericht der deutschen [new German national dish]' (qtd. in Nixon 2011: 206n6). By connecting 'Eintopf' to Irish stew in the typescripts of the English Molloy, through a pun on Irish/arisch in his German diaries - similar to the one on Aryan/Eireann that occurs in Malone Dies (2010: 95-6; see Mooney 2011: 153) - Beckett at least considered associating the nationalism of the Irish Free State with that of Nazi Socialism, both using food as 'lieux de mémoire' (Morin 2005: 229) to fabricate a sense of patriotic unity. Perhaps a word such as 'Eintopf' inserted all too explicitly a notion of politics into the novel, especially since other authors like Victor Klemperer, whose diaries became public in 1947, had already written about it (McNaughton 2018: 13, 171n89). Still, its temporary (re-)occurrence reveals that Beckett continued to draw on different cultures, even in translation, to further shift the cultural affinities of Molloy and deepen its hybridity.

\section{Conclusion}

As our discussion of some genetic variants from the French and English drafts of Molloy has tried to show, the sense of cultural displacement or unbelonging that readers and critics have commonly associated with the novel was only arrived at after a long and careful process of revision. This was marked by considerable hesitation, mirrored in Beckett's acute selfawareness of his dubious position as an Irish expat author wanting to make a literary career for himself in France, from there to attract a global English readership abroad. On the one hand, the genesis of both language versions reveals the resulting bilingual work to be more wordly, perhaps, than it appears in print. On the other hand, one might contend that it remains, 
after all, embedded primarily in a Eurocentric or, if we include the American frame of reference, Western outlook. Still, following Damrosch's distinction of "world literature from a notional "global literature" that might be read solely in airline terminals, unaffected by any specific context whatever' $(2003,25)$, it is not necessary for literary works to be so diluted that they become generic, rid of all nationality. On the contrary, as Vilashini Cooppan states, a work of world literature should at once be 'locally inflected and translocally mobile' (qtd. in Damrosch 2003: 22), regardless of the culture(s) in which it is embedded. Reading Molloy against the Irish-French background from which it emerged, compounded with its forays into English, German and American culture, certainly enriches the experience for readers who are both inclined and equipped to do so. At the same time, Beckett seems to have understood very well that works which 'remain largely within their local or national context, never [achieve] an effective life as world literature' (Damrosch 2003: 289). Delocalizing the novel through its successive draft stages only increased its sense of alienation, which Hill associates with Freud and the umbeimlich (1990: 40). This is a feeling that any reader can relate to, allowing the novel to take on a rich variety of meanings in national contexts far beyond its own, which may already be multiple rather than singular.

\section{Notes}

1 For more information on the translation process of Molloy, Malone Dies and The Unnamable, see O'Reilly, Van Hulle and Verhulst (2017), Van Hulle and Verhulst (2017), and Van Hulle and Weller (2014).

2 This notation refers to the online genetic bilingual edition of Molloy in the Beckett Digital Manuscript Project (www.beckettarchive.org). The reference to the volume (no. 4, edited by Édouard Magessa O'Reilly, Vincent Neyt, Dirk Van Hulle and Pim Verhulst) is followed by the abbreviation of the document in the catalogue (e.g. FN2 is the second French notebook) and the page number.

3 In The Routledge Companion to World Literature (2011), Theo D'Haen, David Damrosch and Djelal Kadir list various disciplines and theoretical fields from which world literature can be analysed, including philology, comparative literature, translation studies, postmodernism and postcolonialism, but genetic criticism or manuscript studies is not one of them.

\section{Works cited}

Beckett, S. (1951), Molloy, Paris: Les Éditions de Minuit. Beckett, S. (2009a), Molloy, London: Faber and Faber. 
Beckett, S. (2009b), Murphy, London: Faber and Faber.

Beckett, S. (2009c), Watt, London: Faber and Faber.

Beckett, S. (2010), Malone Dies, London: Faber and Faber.

Beckett, S. (2011), The Letters of Samuel Beckett, Vol 2: 1941-1956, eds.

George Craig, Martha Dow Fehsenfeld, Dan Gunn, and Lois More Overbeck, Cambridge: Cambridge University Press.

Beckett, S., and E. Franzen (1984), 'Correspondence on Translating Molloy', Babel, 3: 21-35.

'Becketts Blick auf Berlin' (2005), Der Spiegel, 51: 152.

Bixby, P. (2010), 'Beckett at the GPO: Murphy, Ireland, and the "Unhomely", in S. Kennedy (ed.), Beckett and Ireland, 78-95, Cambridge: Cambridge University Press.

Bowles, P. (1994), 'How to Fail: Notes on Talks with Samuel Beckett', The PN Review 96, 20 (4): 24-38.

Damrosch, D. (2003), What Is World Literature? Princeton and Oxford: Princeton University Press.

Davies, W. (2017), “"Home and Visiting Temperaments”: Beckett's Diasporic Encounters', in M. Bariselli, N. M. Bowe, and W. Davies (eds.), Samuel Beckett and Europe, 55-76, Newcastle upon Tyne: Cambridge Scholars Publishing.

de Biasi, P-M. (2004), La génétique des textes, Paris: Nathan.

de St Jorre, J. (2009), The Good Ship Venus: The Erotic Voyage of Maurice Girodias and the Olympia Press, London: Faber and Faber.

D'haen, T., D. Damrosch, and D. Kadir, eds. (2014), The Routledge Companion to World Literature, London and New York: Routledge.

Fletcher, J. (1967), Samuel Beckett's Art, London: Chatto \& Windus.

Harrington, J. P. (1981), 'The Irish Landscape of Samuel Beckett's Watt', The Journal of Narrative Technique, 11 (1): 1-11.

Harrington, J. P. (1991), The Irish Beckett, Syracuse, NY: Syracuse University Press.

Helfand, W. (1991), The Picture of Health: Images of Medicine and Pharmacy from the William H. Helfand Collection, Philadelphia: University of Pennsylvania Press.

Hill, L. (1990), Beckett's Fiction: In Different Words, Cambridge: Cambridge University Press.

Knowlson, J. (1997), Damned to Fame: The Life of Samuel Beckett, London: Bloomsbury.

McNaughton, J. (2018), Samuel Beckett and the Politics of Aftermath, Cambridge: Cambridge University Press.

Mooney, S. (2011), A Tongue Not Mine: Beckett and Translation, Oxford: Oxford University Press.

Morin, E. (2005), "But to Hell with All This Fucking Scenery": Ireland in Translation in Samuel Beckett's Molloy \& Malone Meurt / Malone Dies', in O. Pilný and C. Wallace (eds.), Global Ireland: Irish Literatures for the New Millennium, 222-34, Prague: Litteraria Pragensia.

Morin, E. (2009), Samuel Beckett and the Problem of Irishness, Basingstoke: Palgrave Macmillan.

Neary, J. P., and C. Ó Gráda (1991), 'Protection, Economic War and Structural Change: The 1930s in Ireland', Irish Historical Studies, 27 (107): 250-66. 
Nixon, M. (2011), Samuel Beckett's German Diaries 1936-1937, London: Continuum.

O'Reilly, M., D. Van Hulle, and P. Verhulst (2017), The Making of Samuel Beckett's 'Molloy', Antwerp and London: University Press Antwerp and Bloomsbury.

Rosset, B. (2016), Dear Mr. Beckett: Letters from the Publisher. The Samuel Beckett File, ed. L. Oppenheim, New York: Opus.

Swift, J. (1824), 'A Dialogue in Hybernian Style between A and B', in by Sir W. Scott (ed.), The Works of Jonathan Swift, vol. VIII, 156-7, Edinburgh: Ballantyne.

Van Hulle, D., and P. Verhulst (2017), The Making of Samuel Beckett's 'Malone meurt' / 'Malone Dies', Antwerp and London: University Press Antwerp and Bloomsbury.

Van Hulle, D., and S. Weller (2014), The Making of Samuel Beckett's 'L'Innommable' / 'The Unnamable', Antwerp and London: University Press Antwerp and Bloomsbury.

Winstanley, A. (2014), “Grâce aux excréments des citoyens”: Beckett, Swift and the Coprophagic Economy of Ballyba', Samuel Beckett Today / Aujourd'hui, 26: 91-105. 